Article

\title{
ArcheoGIS for the Roman Thermal Bath of Sofiana: Informative Support for a Digital Restoration
}

\author{
Ornella Fiandaca ${ }^{*}+$ and Giuseppina Salvo ${ }^{*, \dagger}$ \\ Dipartimento di Ingegneria, Università di Messina, 98166 Messina, Italy \\ * Correspondence: ofiandaca@unime.it (O.F.); giusi.salvo@gmail.com (G.S.) \\ † These authors contributed equally to this work.
}

Received: 3 April 2019; Accepted: 19 May 2019; Published: 30 May 2019

\begin{abstract}
In connection to the vast archaeological area of Sofiana, which is still periodically subjected to excavation campaigns, the investigated thermal complex represents the first emersion that occurred in the 1950s and testifies to all the limits of a premature methodological acquisition of both the documentation for cognition as well as the interventions of detection and restoration. This zone, considered by archaeologists as a concluded episode, was used by us as a test bench for a method of investigation from which to start again in order to supply missing information. We set aside all the information acquired over time with other traditional and innovative tools and visions and used a more accurate dimensional geometric survey with a laser scanner, a typological analysis confronted with similar experiences, and a constructive technical study enriched with diagnostic investigations, to provide new data to be collected and processed. Thus, a geographic information system (GIS) platform was chosen as an information technology (IT) tool to contain direct information and data processing. The outcomes of ArcheoGIS were used to derive the initial answers to the questions we asked ourselves, namely, how can the constantly evolving knowledge of this archaeological find be spread and what path can be taken to propose philological restorations of the portions of Sofiana to which a correct virtual disassembly is feasible?
\end{abstract}

Keywords: ArcheoGIS; geographic information system (GIS); Sofiana; laser scanner; diagnostic tests

\section{A New Cognitive Course for Sofiana}

The archaeological area of Sofiana (also called Sophiana and Philosophiana [1]), falling within the homonymous district of the Mazzarinese countryside (CL), is under the administrative control of the Villa del Casale Archaeological Park in Piazza Armerina (EN; Figures 1 and 2).

Although the settlement consists of several historical and building phases with material traces referable to both prehistoric and postclassical periods, the visible part that has been preserved includes wall structures belonging to various kinds of buildings dating from the II-III centuries AD; the material and constructive evidences go, it is not clear whether with continuity, until the late antiquity and the Middle Ages.

Specifically, the area includes urban structures recognised as boundary walls; residential buildings (a domus); roads, of which one is paved, with others perpendicular to it; a series of workshops; a monumental fountain overlooking the street; and a large complex probably for public thermal use [2]. The structure of the latter was based on pre-existing contemporary construction from the urban settlement of the II century AD, but with a primitive core from the Constantinian age and its numerous subsequent annexations. Outside the walls, there is also an early Christian basilica with a sepulchral area both inside the building and outside the apses [3,4] (Figure 3).

Starting from the material from various field research and archaeological excavation missions since the 1950s, attention was focused on the thermal complex that was highlighted during a bibliographical 
and autopsy study to have temporal inconsistencies, knowledge gaps and, above all, an unclear overlapping of historical phases that was further confused by a restoration carried out with almost completely absent documentary support [2-4]. From 2015, we devoted a new focus to this find which has been abandoned since the 1990s. In particular, it was addressed with different investigative and multidisciplinary approaches in order to arrive at the definition of a methodology that, from the absence of concrete archaeological evidence, can reconstruct a platform of knowledge to which scholars and operators will be able to resort for advice on real or virtual restorations or de-restorations.

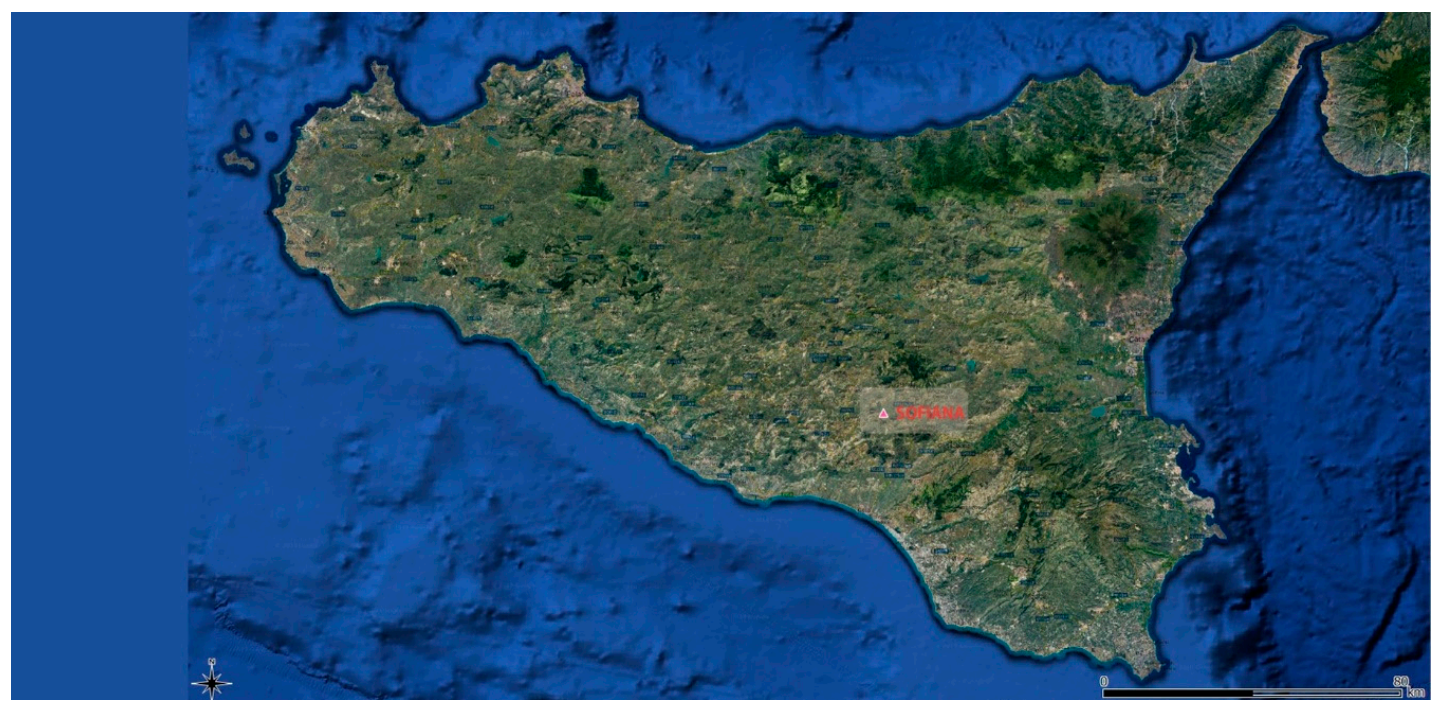

Figure 1. Sophiana in the Sicily context.

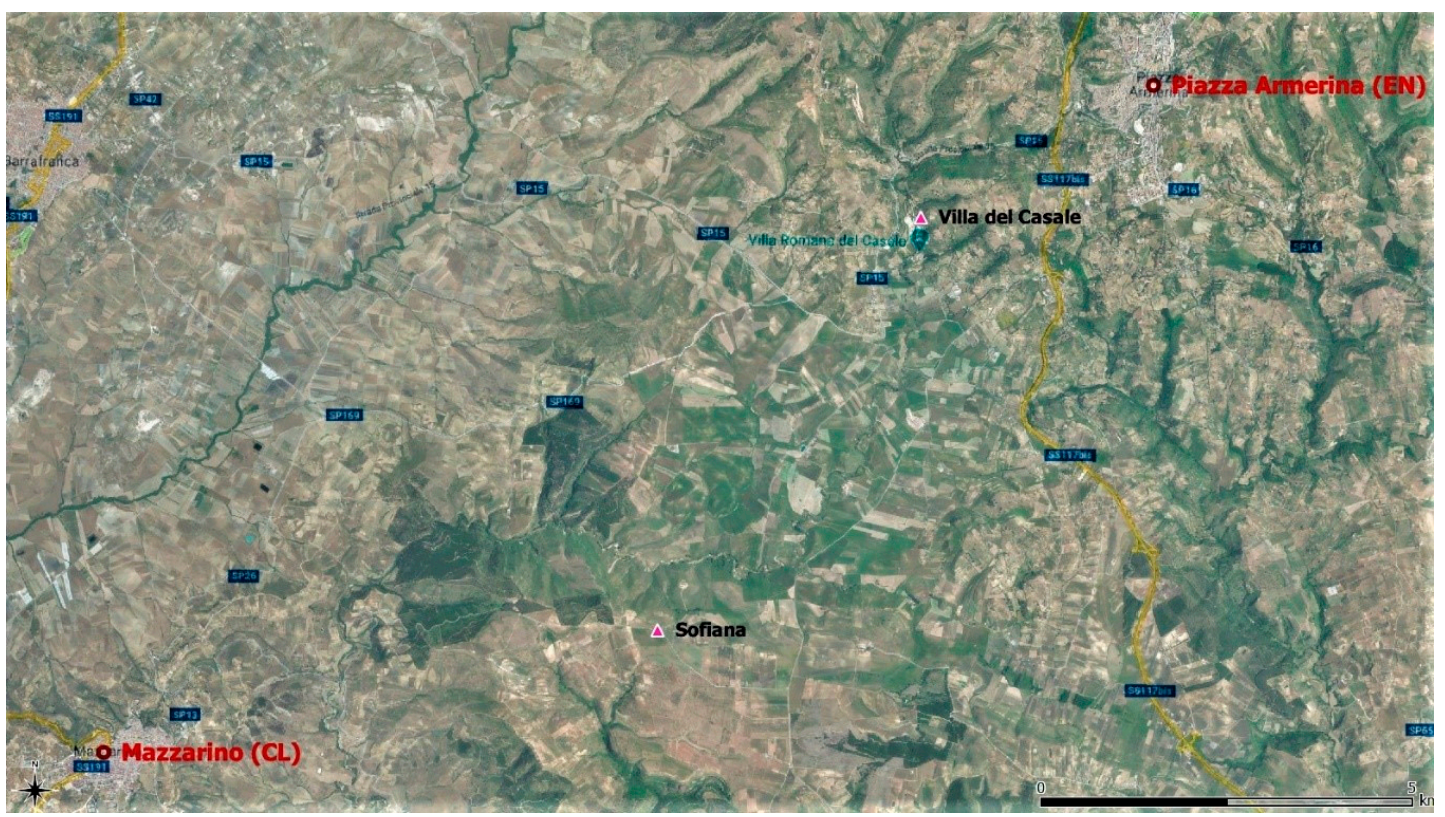

Figure 2. Territorial framework. Overlay of Google Earth with the orthophotos (2012 flight) to highlight the topographical positions of Sofiana and the Villa del Casale, with respect to the inhabited centres of Piazza Armerina and Mazzarino.

In the first phase, therefore, a geometric-dimensional field survey was carried out with the aid of a topographic laser scanner, integrating the previous data acquired with analogical instruments [5-7].

A further contribution, carried out through some peculiar typological comparisons, was needed to provide a greater comprehension of functional distribution both on a detailed scale and on the 
urban relationship with the surrounding area; not only through the alignments of the stone walls, but by deciphering the morphology of the territory in relation to the water supply and to the resources necessary for the operation of the thermal complex (primarily the procurement of wood to burn) [8-11].

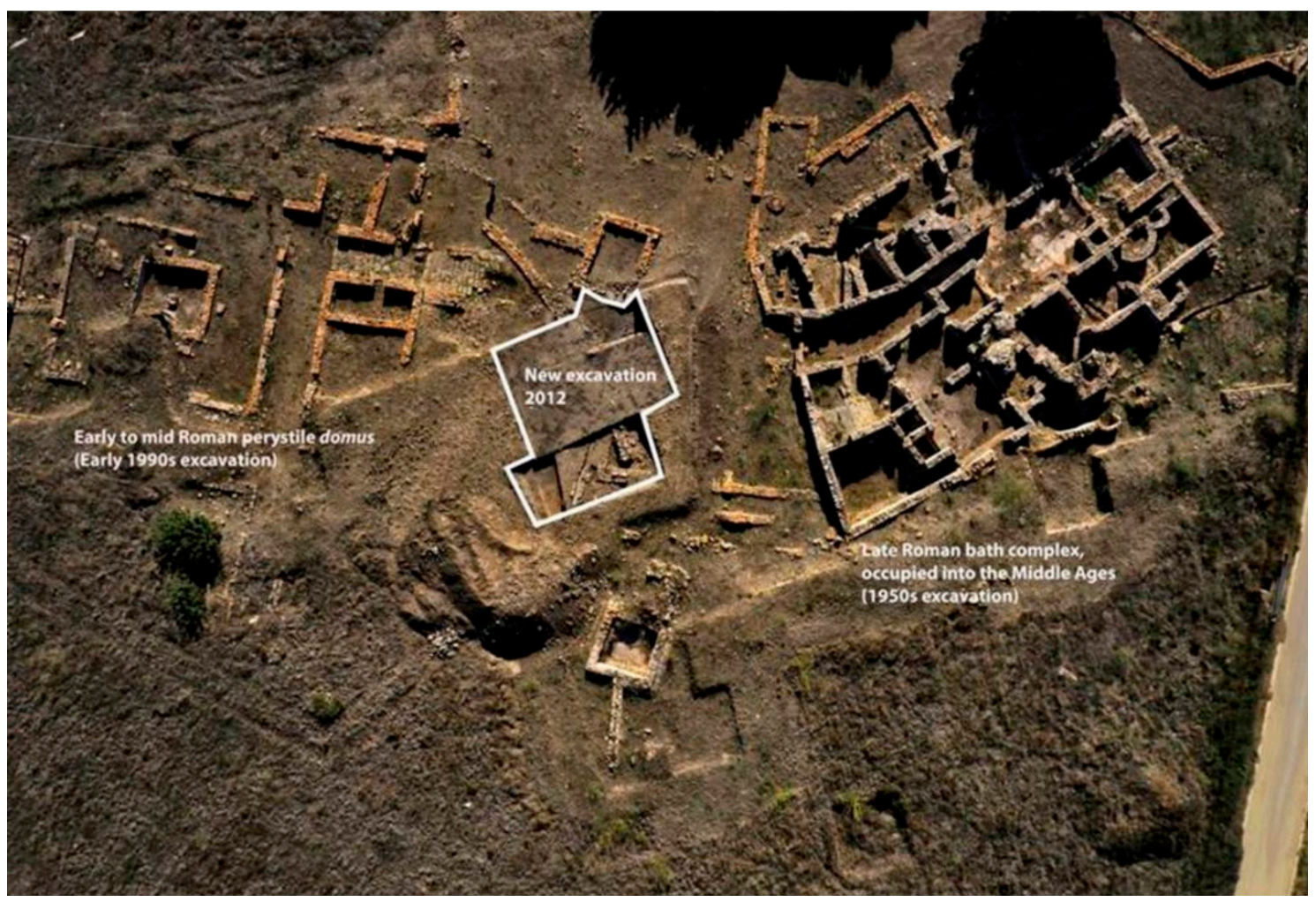

Figure 3. Archaeological structures (the site including the Early Christian Basilica out of this plant).

The integration was completed with a survey of a specifically technical-constructive nature that produced the revision of the cataloguing of the Masonry Stratigraphic Units (in Italy USM) and the Cladding Stratigraphic Units (in Italy USR) using the official ministerial documents for the archaeology as conceptual support for the completeness of the contents. These actions were then enriched with diagnostic investigations to gain the knowledge about the materials and their territorial availability [11].

\section{ArcheoGIS: Structure and Contents}

To dynamically manage the data acquired during this study, and increase their ease of use despite their different and presumably distant nature, a "digital container" was conceived by adopting the open source QGIS (software GPL, ver. 3.4.5) and appointing the project ArcheoGIS to exploit the potential of the information system when applied to the archeological sector [12-15]. First of all, the choice of a GIS platform to be used as a variegated container of information was dictated by the need and desire to make fields of study that are apparently independent of each other coexist and meet. With a view to sharing and interconnecting multidisciplinary experiences, this digital report tool immediately proved to be suitable and versatile.

Historical and modern cartographies were put into a system, and relationships were determined between them and were taken as bases on which to locate-from the macro to the micro scale- - the entire Contrada Sofiana, the archaeological area, the structures, and specifically, the Spa with its constructive parts to reach the level of detail of the constituent components (stones, bricks, coccipesti, marbles, metals, etc.). All of this was done in a reversible vista of "zoom in" and "zoom out" allowing minor or greater knowledge deepening by accessing external contents that could be recalled.

Specifically, the macrolemmi of the structure were used for the most immediate synthesis of the project: from the satellite view with cadastral details (updated to 2019) to the navigable and interactive 
inventory of the materials produced in the previous phases of study on the archaeological site in general and, in particular, with the other new contributions, to the existing and possible comparisons (Figure 4).

In a flow chart (Figure 5) the conceived structure application of the QGIS (Archeo.GIS) is presented and the related contents are briefly explained.

We decided to present the results of the technical-constructive analysis as a methodological deepening, bearing in mind however, that this is a work in progress in which the quality of the instruments is versatile, and the project has the possibility of being continuously implemented.

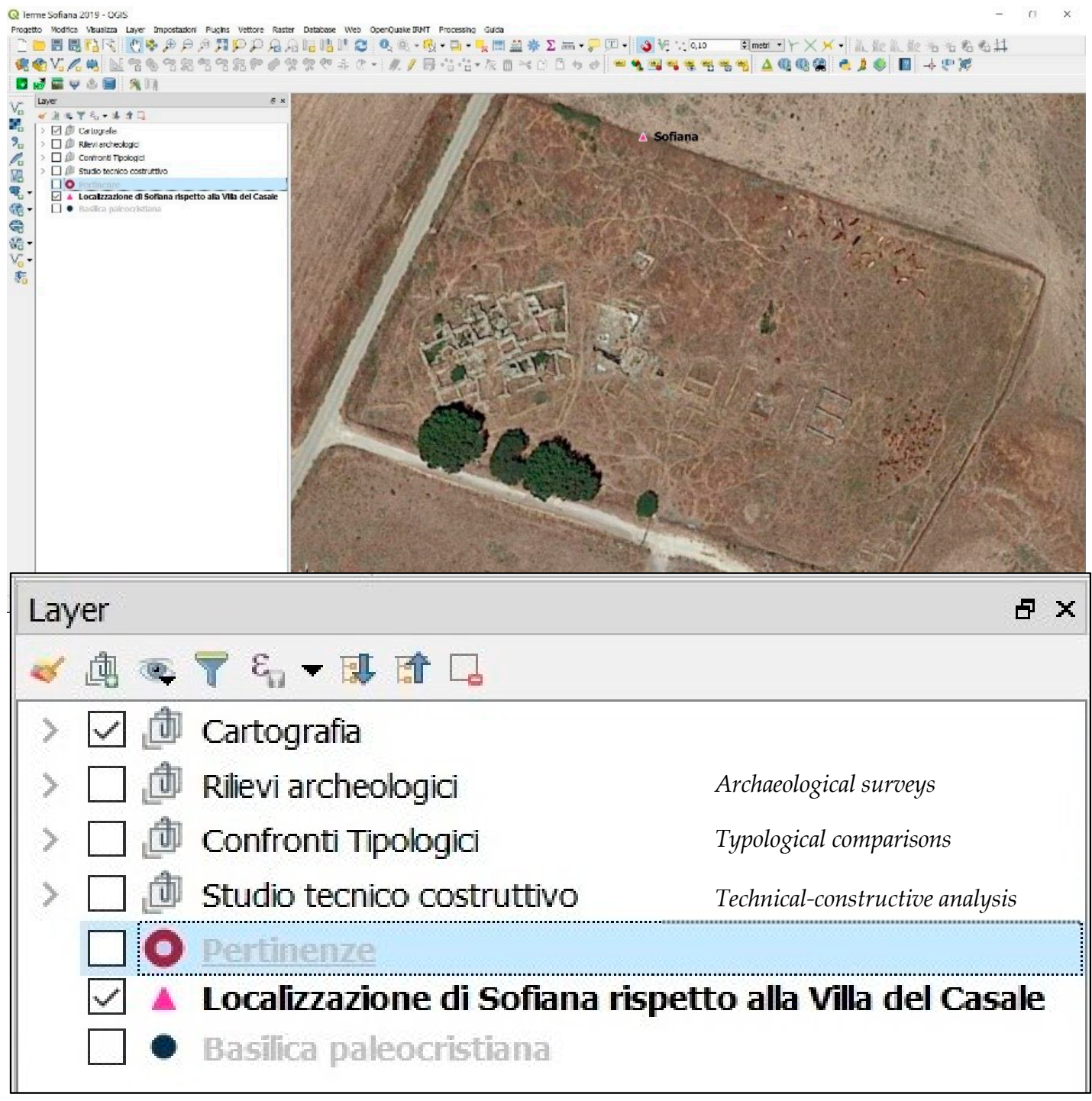

Figure 4. General structure of the ArcheoGIS (above) and zoom of the macrolemmi (below).

\subsection{Archaeological Surveys}

From the first investigations following the discovery of Professor Adamesteanu (1954) of the planimetry elaboration of the Baths and the Early Christian Basilica, we moved on to the interpretative hypotheses of Professor Wilson (1990), summarized in his relief with descriptions of the construction phases in chronological order, to attain the most detailed archaeological drawings of the Baths performed by Professor La Torre (1989-1990) during the excavation of the town, which was inhabited in the Imperial Age. Finally, digitalization of the same was obtained during the Philosophiana Project (2013-2016) under the joint direction of the Professors La Torre and Vaccaro [2-4] (Figure 6). 


\section{FLOW CHART}
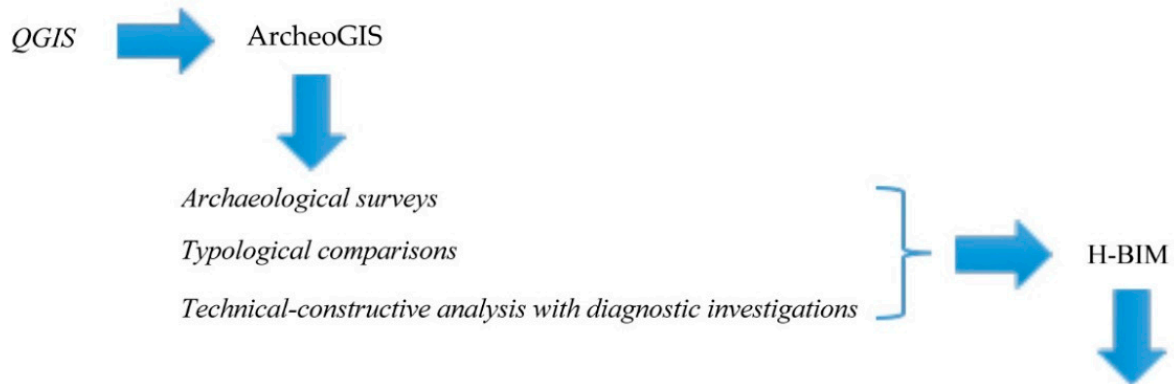

Real archaeological restoration

Virtual archaeological restoration

Figure 5. Flowchart of the adopted methodology.
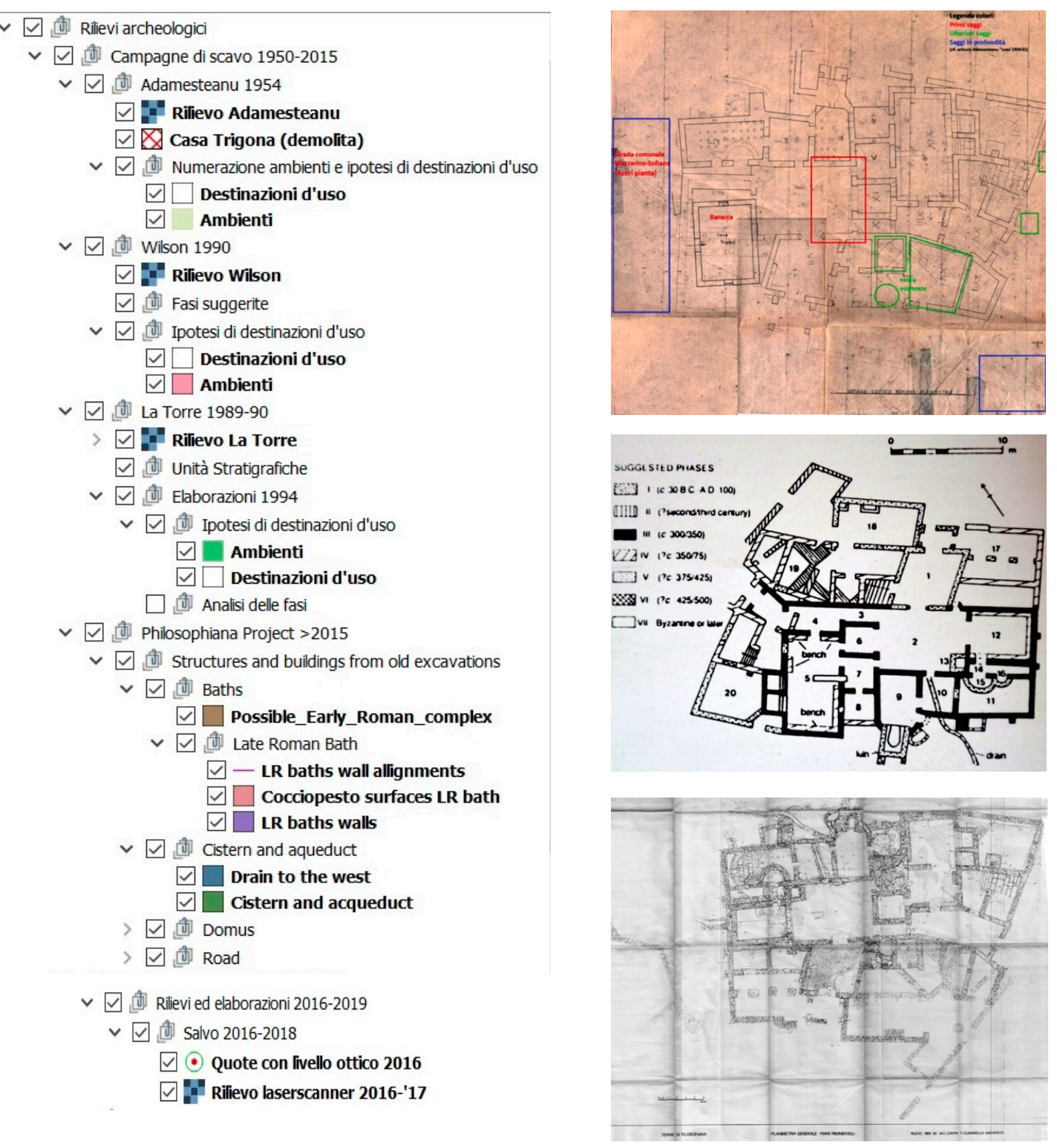

Figure 6. "Archaeological surveys": substructure and contents (left); Adamesteanu, Wilson, La Torre reliefs (right). 
Each "historised" paper pertaining to the thermal complex has been subject to verification in the field as a preliminary analysis, followed by a geometric-dimensional study and a material-constructive one.

The geometric-dimensional study was carried out with a topographic laser scanner that returned a $3 \mathrm{D}$ point cloud to superimpose on the previous documents, hence arriving at a correct geo-referencing survey (Figure 7).

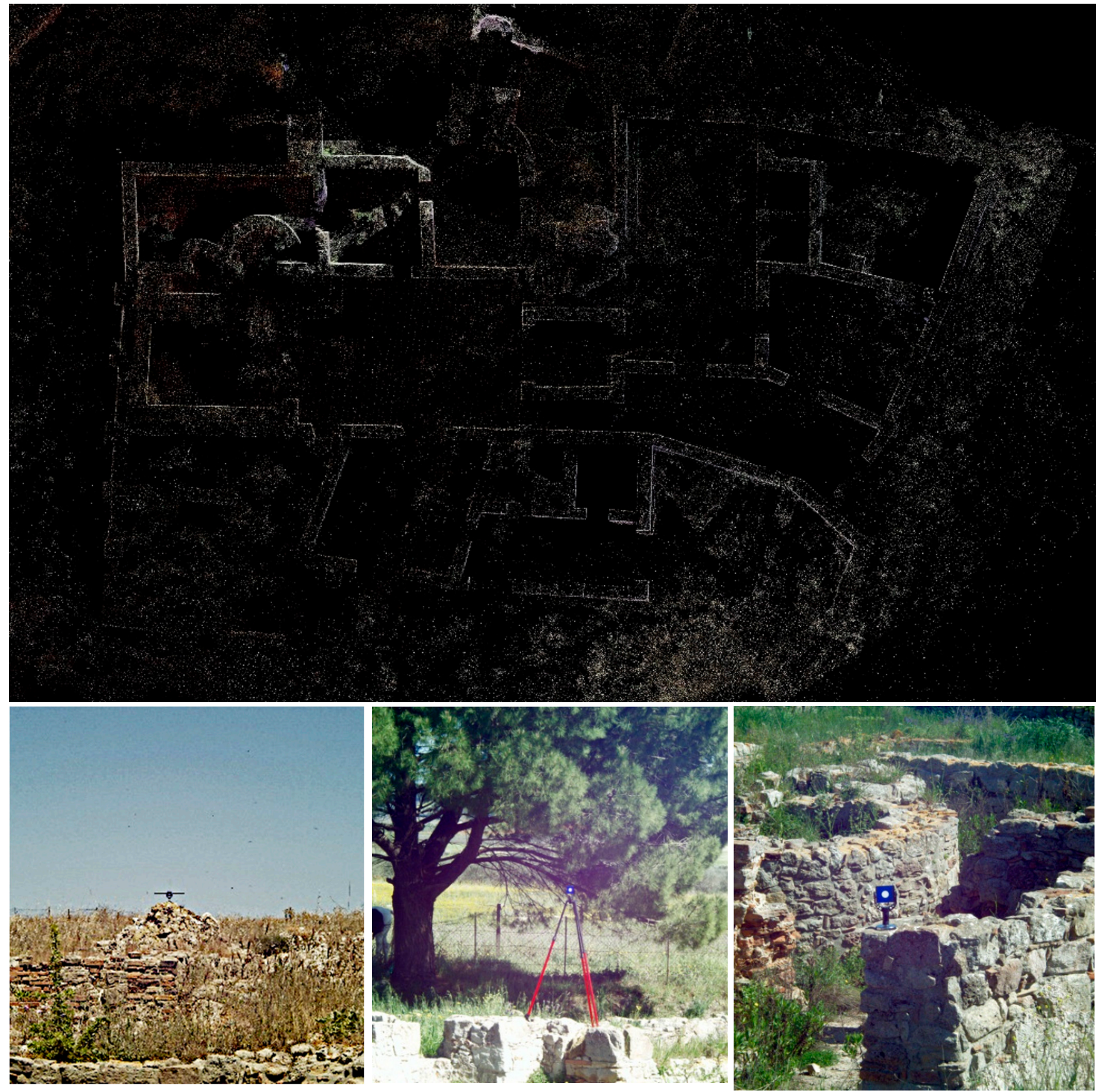

Figure 7. Laser scanner survey: point cloud (above) and targeting of some fiduciary points (below) [7].

The material-constructive study, which was very incomplete in previous studies, is the heart of our research and is described in greater detail in Section 2.3.

Both surveys support the identification of the different historical phases.

\subsection{Typological Comparisons}

To proceed with the reconstructive hypotheses, even where chronologically probable, Sofiana was compared to other archaeological sites, mainly Sicilian sites, which had thermal construction with similar distribution-functional characteristics [10], in order to draw useful clues for new interpretations and confirmations of previous ones (Figure 8). In this sense, some of the Sicilian thermal baths on the 
route of the Roman Catania-Agrigento road were selected, of which Sofiana was a resting place with a thermal complex for public use.
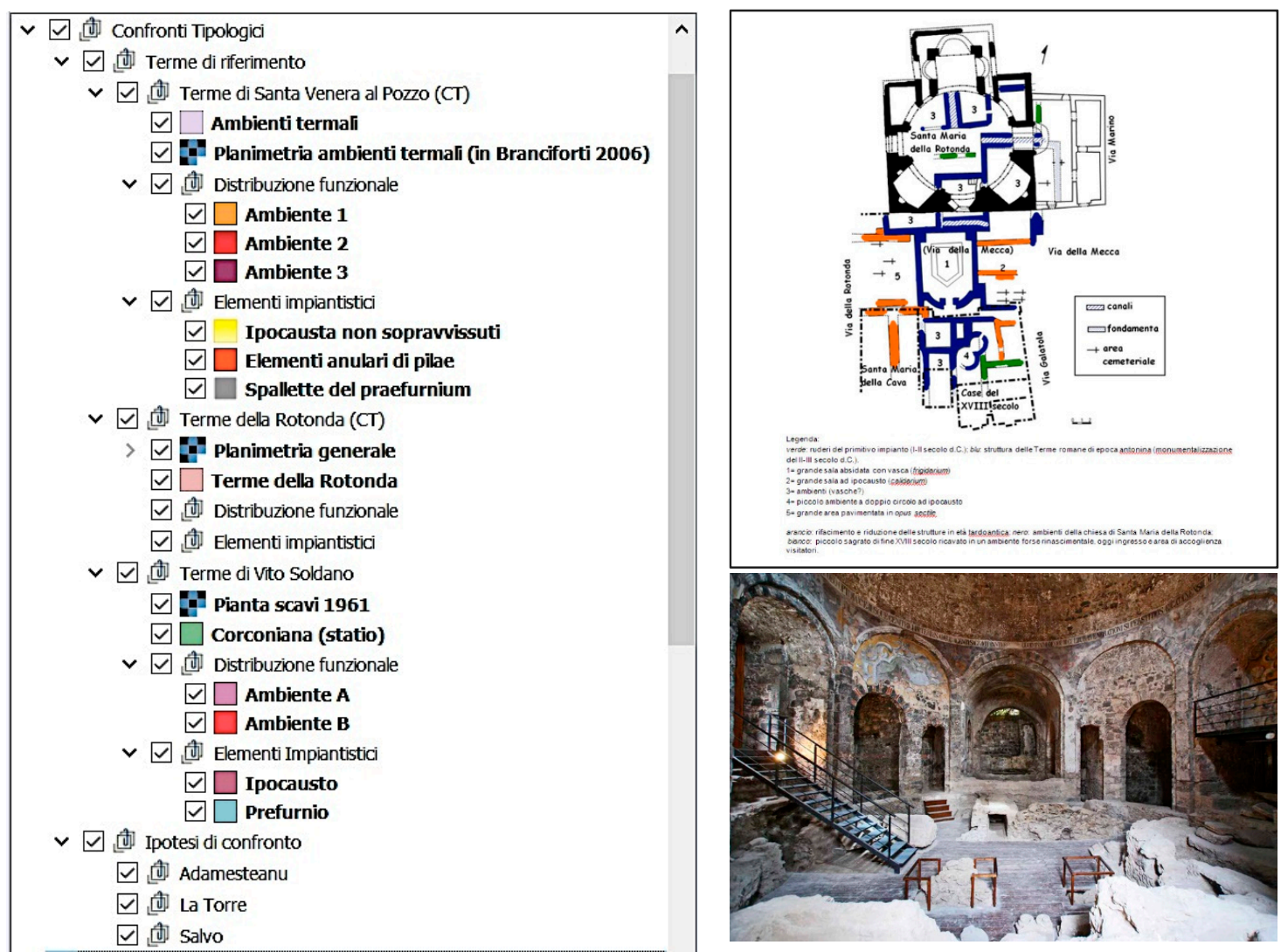

Figure 8. “Typological comparisons": substructure and contents (left); Bath of Rotonda-CT (right).

Afterwards, the presumed statio of Santa Venera al Pozzo (Acicatena, CT) was inserted with the survival of two environments, intact in the roofs, recognisable as being heated from an underfloor heating system (hypocaust). For this reason, it seemed to be part of a thermal area, which was perhaps also public. Similarly, the so-called Rotonda (CT) complex was studied, which presented different phases and wall additions with a global readability and was clear enough to conduct a second typological comparison [8].

Only one last plant is mentioned here-the Vito Soldano (Canicatti/Castrofilippo, AG)—which is recognized as part of the certificated Corconiana statio, cited together with Philosophiana/Sophiana in the Itinerarium Antonini [9].

Initially the structures has been localized at the territorial and urban levels, before proceeding to planimetric-distributive details with the definition of the environments and the related functions, and then moving up to the scale of hydraulic detail with the recognition of the peculiar elements of the facilities for non-natural thermal bathing i.e., with forced heating (Figure 9). 


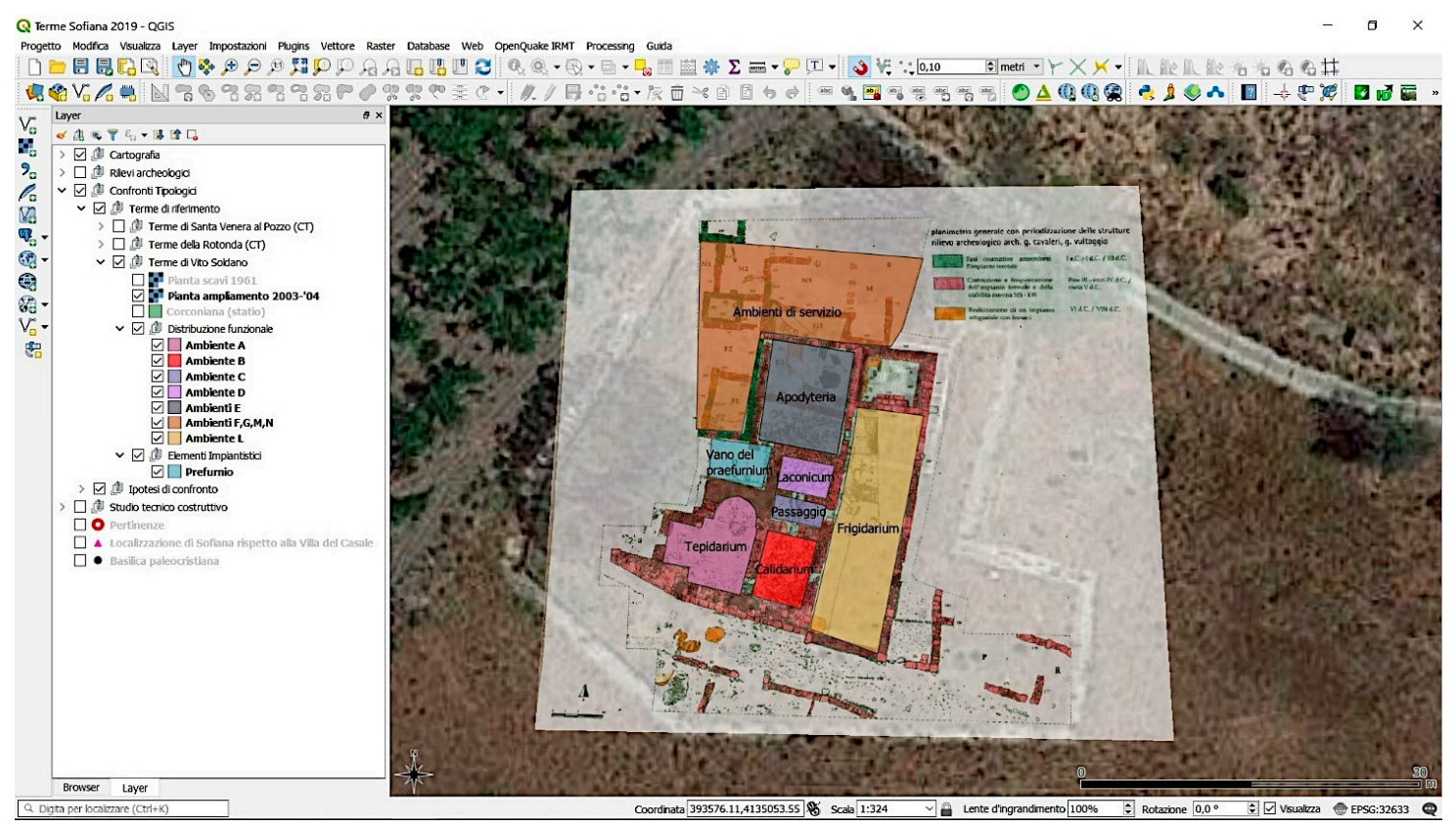

Figure 9. Typological comparison of Vito Soldano (AG)/statio Corconiana. On the satellite image, we geo-referenced the archaeological planimetry andhighlighted the environments, distinguished by function.

\subsection{Technical-Constructive Analysis with Diagnostic Investigations}

In the last macro group, which summarizes the heart of the research work, technical-constructive analyses were carried out at various levels, in the field and in the laboratory, on the thermal baths as a whole and on each constituent element in detail (Figure 10).

In this way, it was possible to pass from the autopsy study of the masonry through the systematisation (in tabs) of the detailed photographic survey located on the planimetry and accompanied by the very first reflections emerging from personal observations to the editing of the Masonry Stratigraphic Units and Cladding Stratigraphic Units cards. All that of the explanatory information was derived from diagnostic investigations on stones, mortars and clay materials. In fact, mineralogical-petrographic type tests were performed with spectroscopy on thin sections taken from lithic and mortar samples and with IR technology on brick and cocciopesto samples.

During field inspections, an "expeditious" survey was carried out on the material of the masonry systems and of the floor and wall coverings, from which a first general planimetry distinguished the types of construction element surviving (mortar, cocciopesto, stone) at the time and the shortcomings of the technical and archaeological drawings of La Torre as a form of basic support [2,4] (Figure 11). An exemplary "USM card" was developed for each element (masonry or cladding) that specified the construction techniques of the masonry, and highlighted its peculiar elements and both the material and morphological nature of the components.

The laboratory tests allowed us to confirm the supply area of the basic materials used in the construction (which, as imagined, was in the surrounds of Sofiana), but also to advance further hypotheses validated by the findings of contemporaneity or diachronicity in the production or in the reuse, above all, of the fictile elements from previous phases of the thermal complex themselves and the neighbouring residential settlement. 
(1) Studio tecnico costruttivo

$\checkmark \square$ (A) Rilevo tecnico-costruttivo

$\checkmark$ Murature e impianti

$\checkmark$ (4) Rivestimenti pavimental e parietall

$\checkmark \square$ Integrazioni diagnostiche

$>\square$ Material litici

$>\square$ Conglomerati

$>\square$ Malte

$>\square$ Laterizi

$\checkmark \square$ (t) Schedatura tipi murari

$\checkmark$ US La Torre

$\checkmark \square$ US Salvo

$\checkmark$ (t) USM

$\checkmark$ (1) USR

$\checkmark \checkmark$ Alineamenti murari

$\square$ - Allineamenti con scavo di II sec. d. C.

$\checkmark \square$ If Impianti

$\square$ (4) Distribuzione funzionale

$\checkmark \square$ Elementi impiantistio

$\square \square$ Alloggiamenti per cisterne metalliche

$\checkmark .$. Pavimenti sospesi

$\checkmark$ Ipocausta esistenti

$\checkmark \Delta$ Ipocausta non sopravvissuti

$\checkmark \square$ Fistulae metalliche

$\square \square$ Canalizzazioni idrauliche

$\square \square$ Vasche e piscine

$\checkmark \square$ pilae (quadrate)

$\checkmark \square$ Plae (anulari)

$\checkmark$ Praefurnia

$\checkmark \square$ (i) Reperibilità dei materiali ipotizzata

$>$ Carta geologica
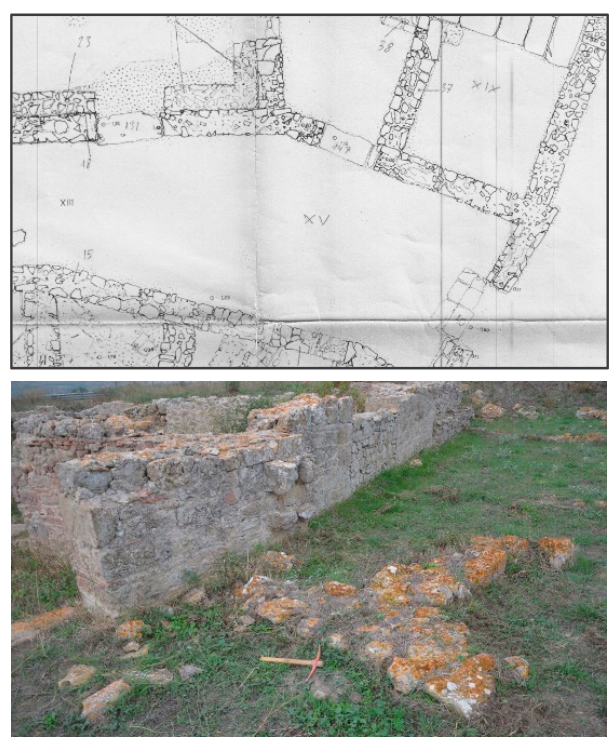

Figure 10. "Technical-constructive study": substructure and contents (left); photo of technical relief (right).

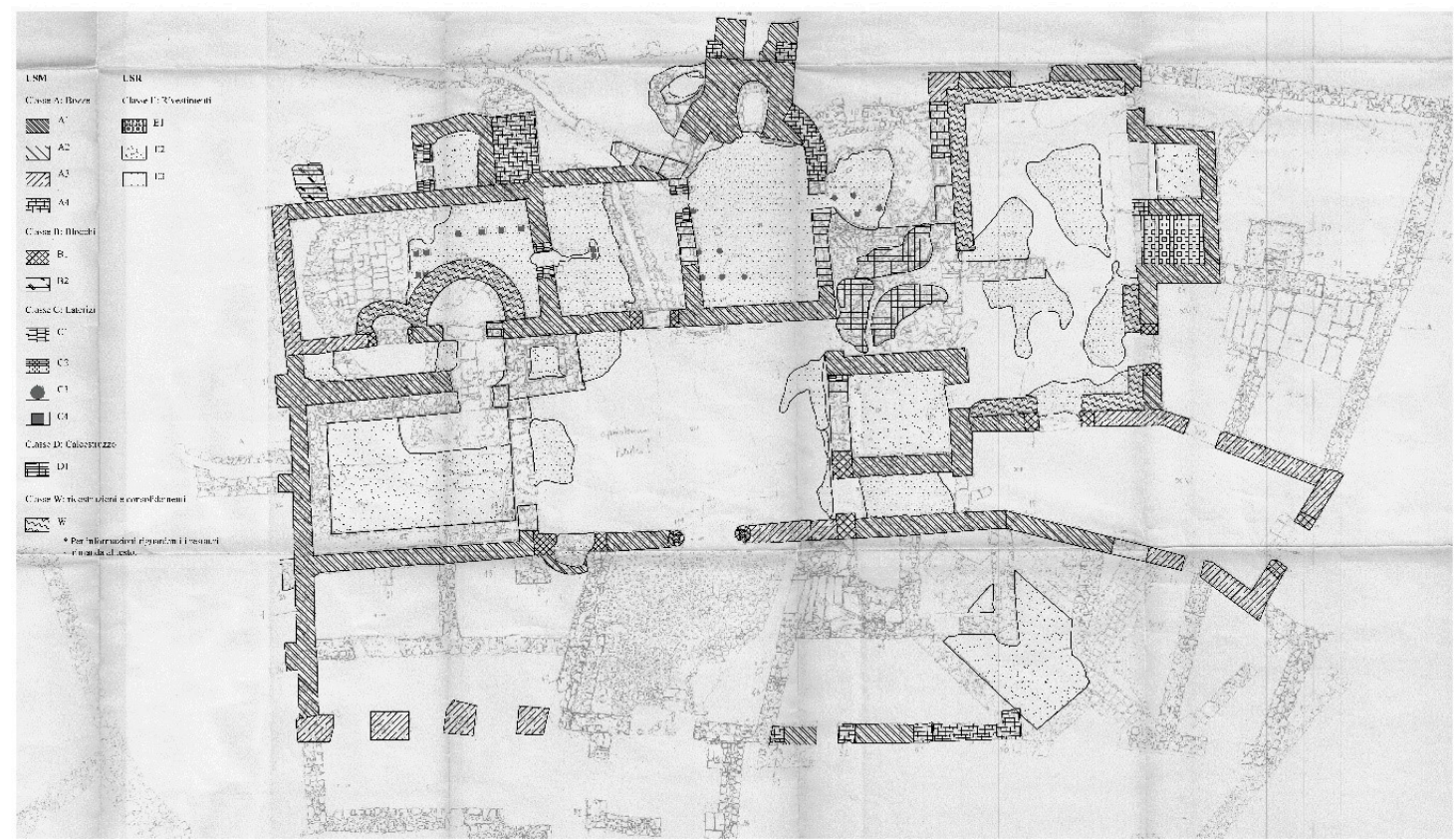

Figure 11. General plan with the results of technical-construction surveys (Processing of the authors). 


\section{A Methodological Focus}

Each sections briefly described was undergoing continuous processing to reach the definition of the results to be included in the ArcheoGIS. So, as a methodological study, this last part presents what was produced by interweaving the various sources. We also draw on the other themes used to extrapolate the information associated with the USM and USR to identify attributes to be included in the elaborated informative instrument $[7,13]$.

\section{Masonry Stratigraphic Units (USM) and Cladding Stratigraphic Units (USR)}

The cards, drawn up separately for the USM and USR, contain an increasingly detailed analysis going from their recognition of the construction elements to the photographic apparatus for the documentation of the sample locations until diagnostic analysis of the materials. An introductory table proposes a general synopsis that serves as the identity card of the USM, because it contains their general planimetry and locations with respect to the thermal complex with an overall photograph accompanied by a brief description (USM: Figure 12a; USR: Figure 12e).

A sheet of the first series enters into the specifics of the individual elements that make up the USM, providing a side-by-side image of a technical-construction relief that illustrates, in detail, the subsequent description of "opus" and the texture used in their confection (Figure 12b). Once the macroscopic scale information is exhausted, the details of the constituent materials is entered into the following "sheets". Thus, in the third sheet, the photograph of the sample on a real scale is enriched by the whole set of scientific data obtained from the laboratory analyses and the information that allowed us to extrapolate and deduce the same. The piece, univocally identified and planimetrically and altimetrically located, is filed according to dimensions and macroscopic characteristics determined from the preliminary autopsy analysis (inclusions, hardness, colour, etc.) and, where available and significant, the section is photographed (Figure 12c). A third sheet gives the outcome of the petrographic-mineralogical analysis of the stone samples and conglomerates with the description of the optical microscope observations or the SEM microscope observations to catch the otherwise unseen details (Figure 12d).

The USR cards faithfully follow the contents of the already described USM, as the analyses carried out on the material samples are the same. Only the last includes the diffractometric profile derived from IR technology analyses and a semiquantitative count and analysis of the main minerals present in the sample of the cocciopesto coating (Figure 12f-h). 


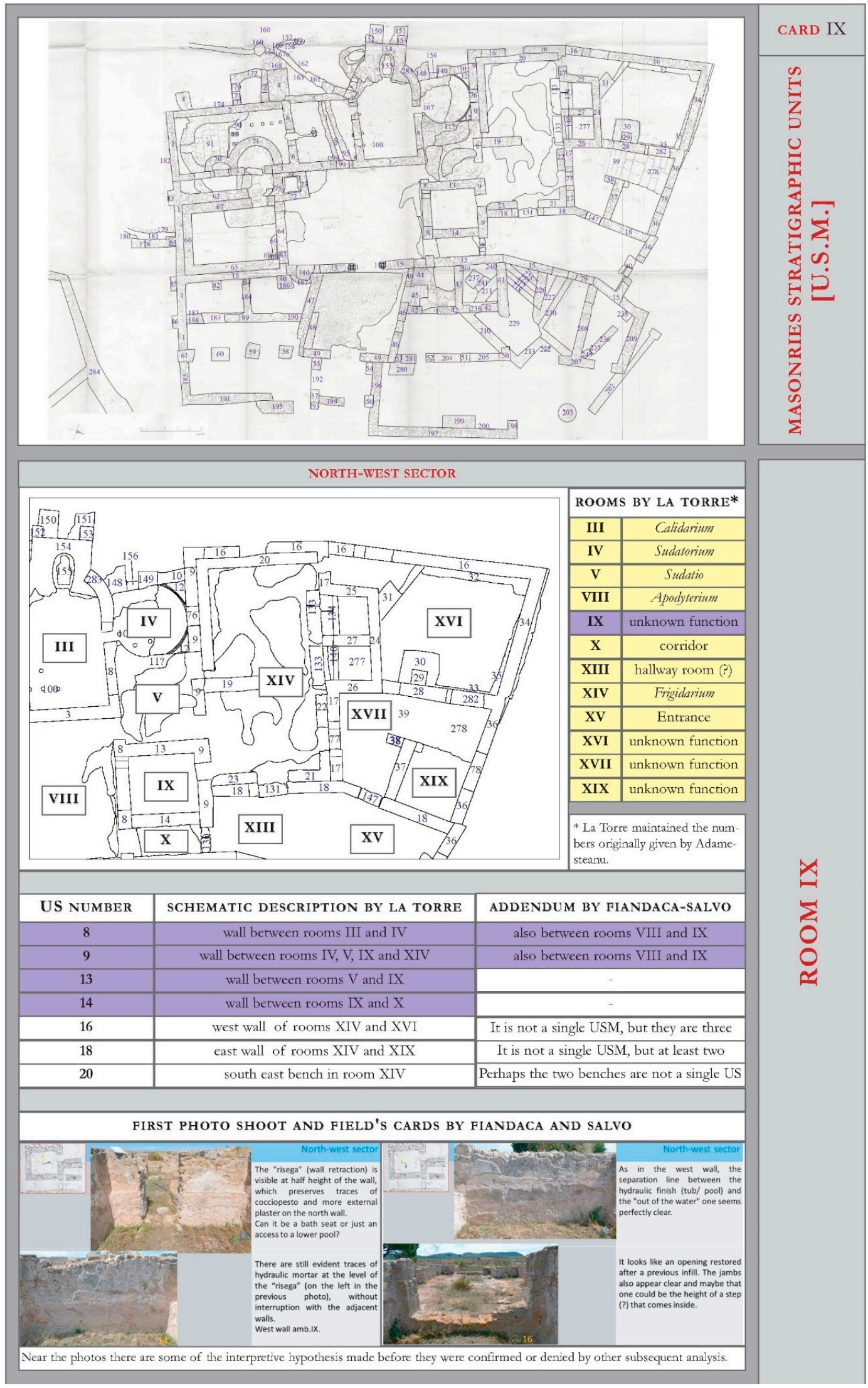

(a)

Figure 12. Cont. 

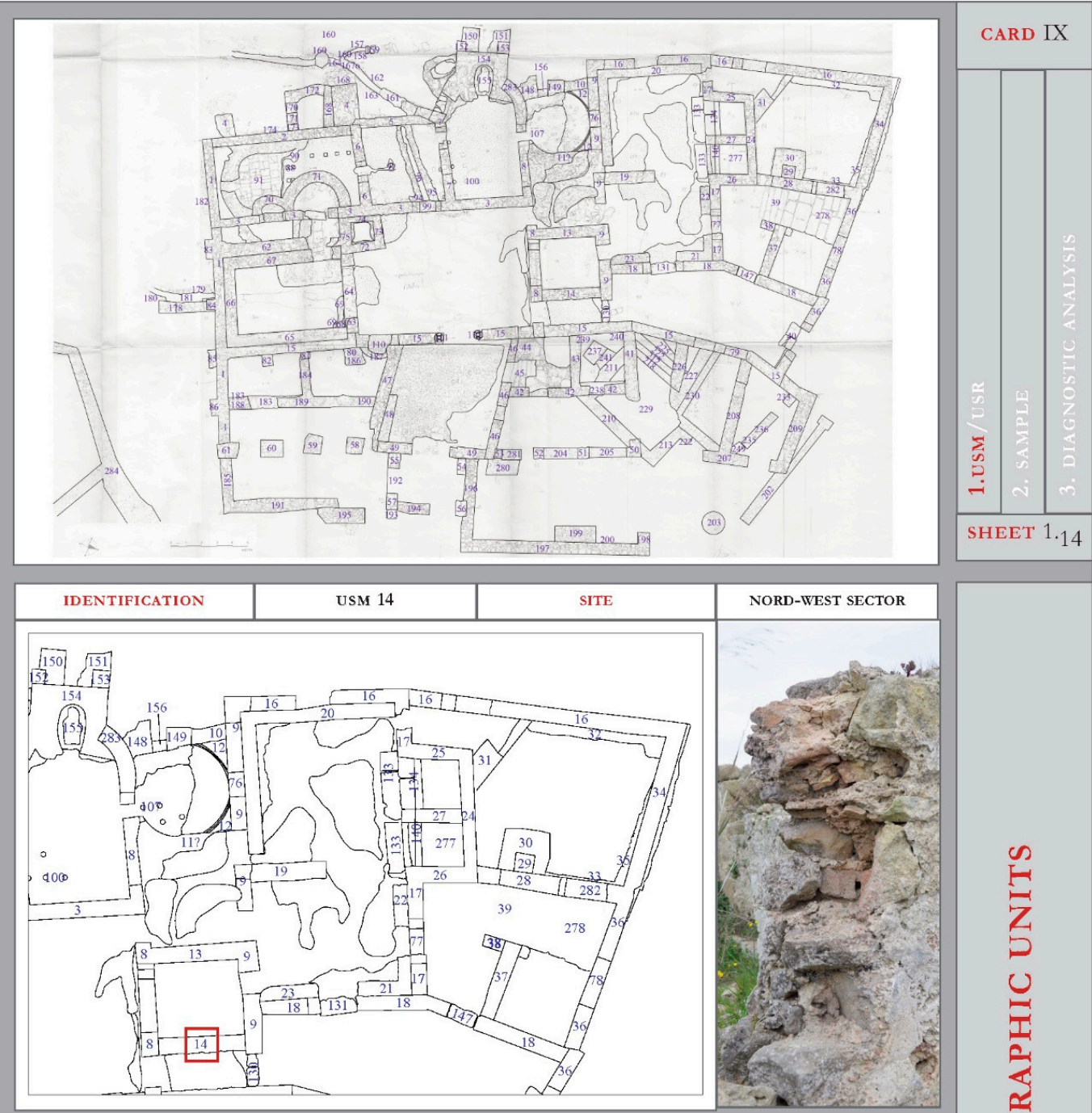

\begin{tabular}{|c|c|}
\hline \multicolumn{2}{|c|}{ BUILDING MATERIALS AND CONSTRUCTION TECNIQUE } \\
\hline MANSORY TYPE & A1 \\
\hline TYPOLOGICAL DEFINITION & $\begin{array}{c}\text { Irregular masonry in calcarenite and stuck core with wedges in flat and thin tiles and / or } \\
\text { splinters }\end{array}$ \\
\hline
\end{tabular}

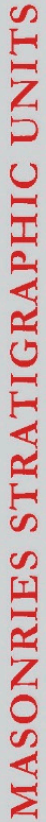

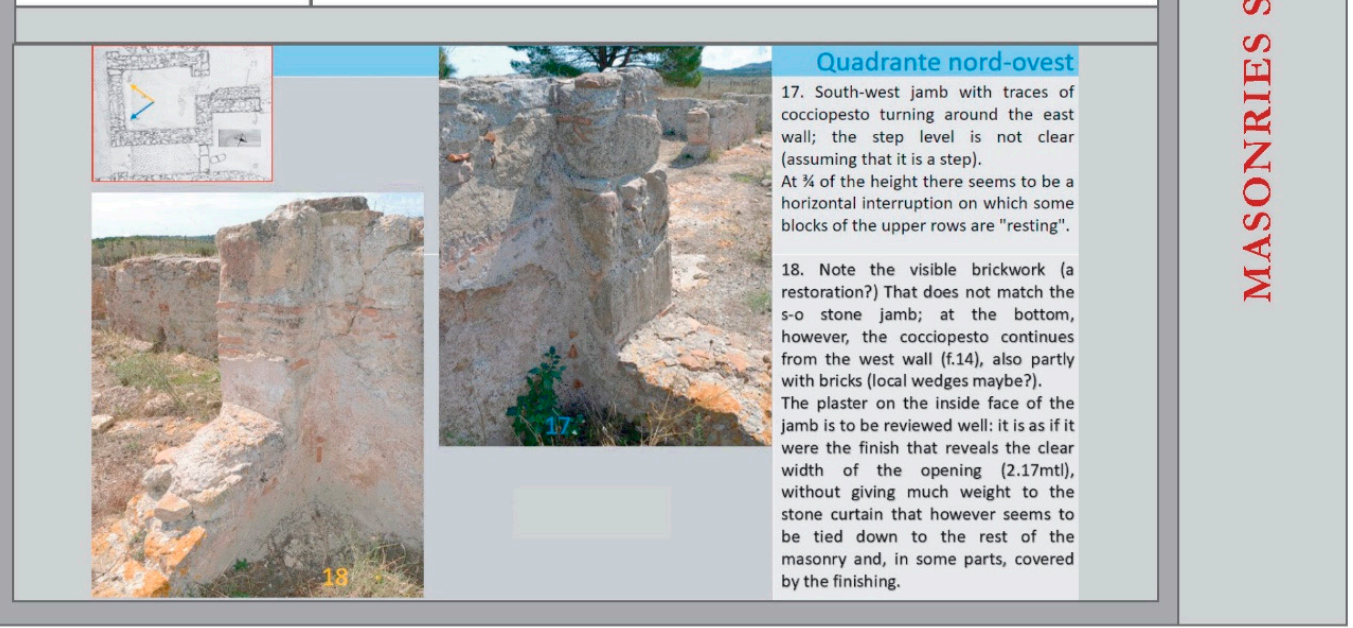

(b)

Figure 12. Cont. 


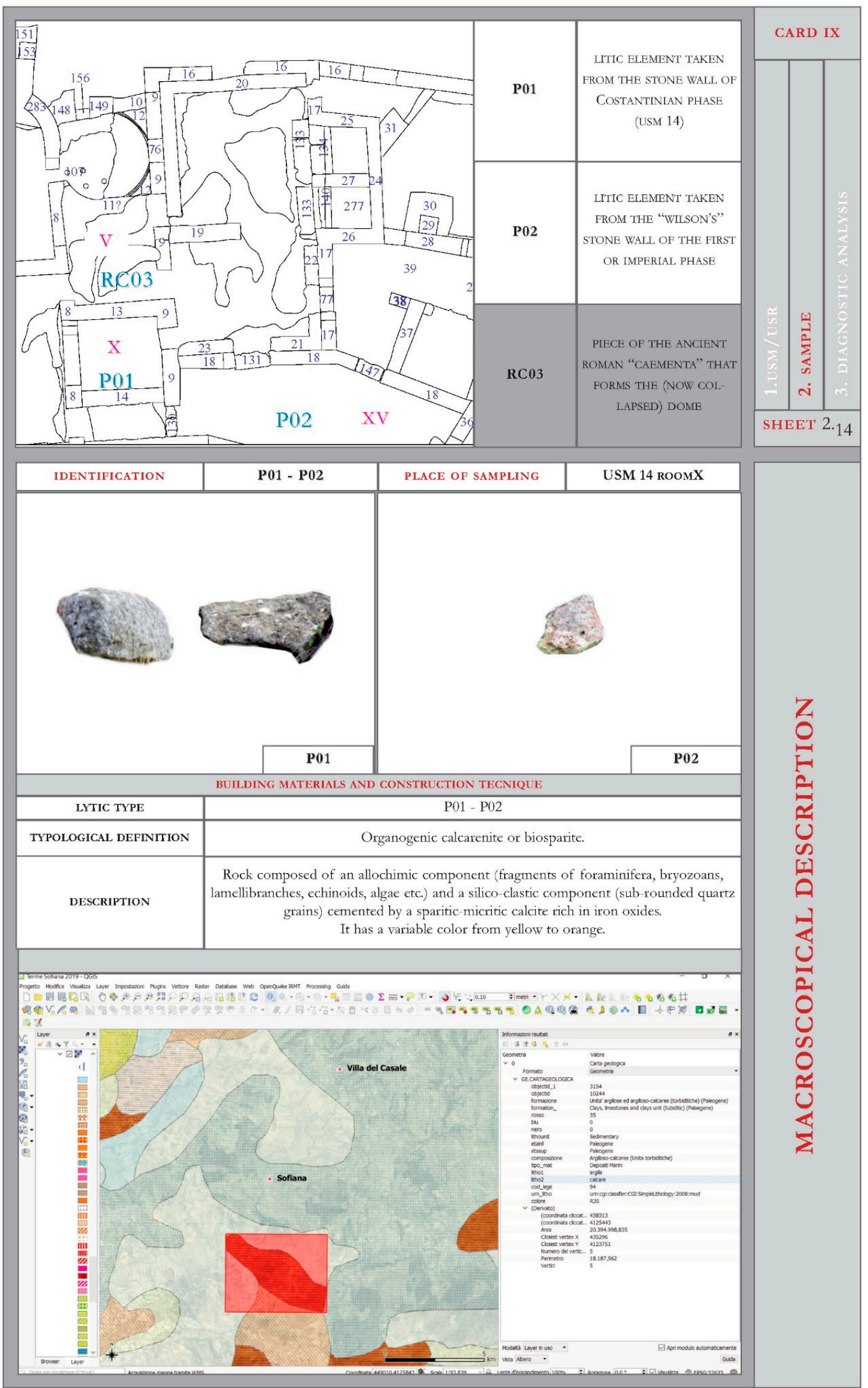

(c)

Figure 12. Cont. 

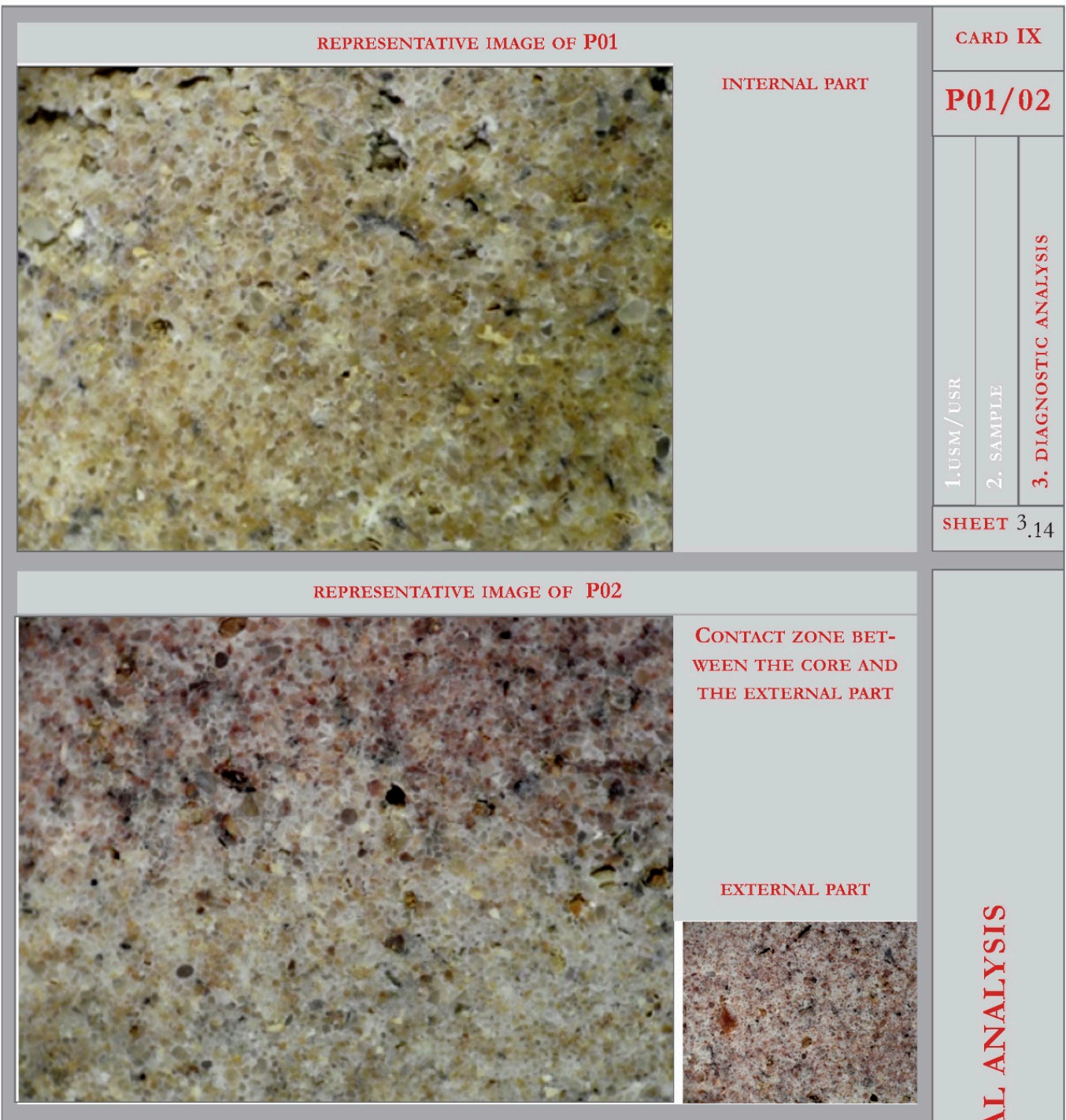

INTERPRETATION

The two samples taken in different areas have returned the same mineralogical petrographic nature to an observation in thin section, highlighting a finding in homogeneous quarry of the natural lithic elements, which is also found in the aggregates detected in the mortars.

Therefore the stonc material of all the walls is the same.

The construction technique, the type of appliance and the size of the basic elements change, identifying different construction phases.

Then a morphological study was added to the diagnostic investigations to distinguish above all the original parts from the reconstructed crests being restored.

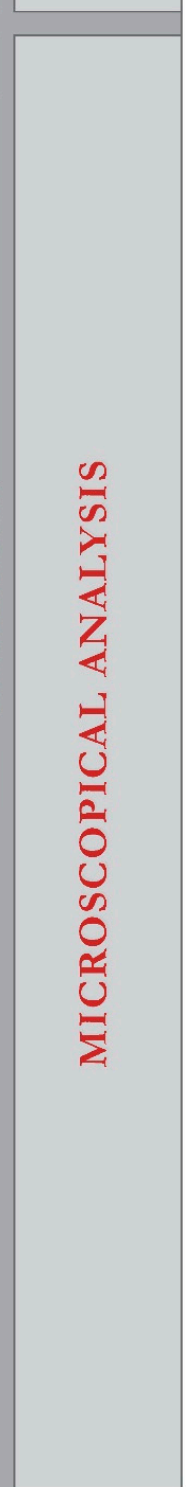

(d)

Figure 12. Cont. 

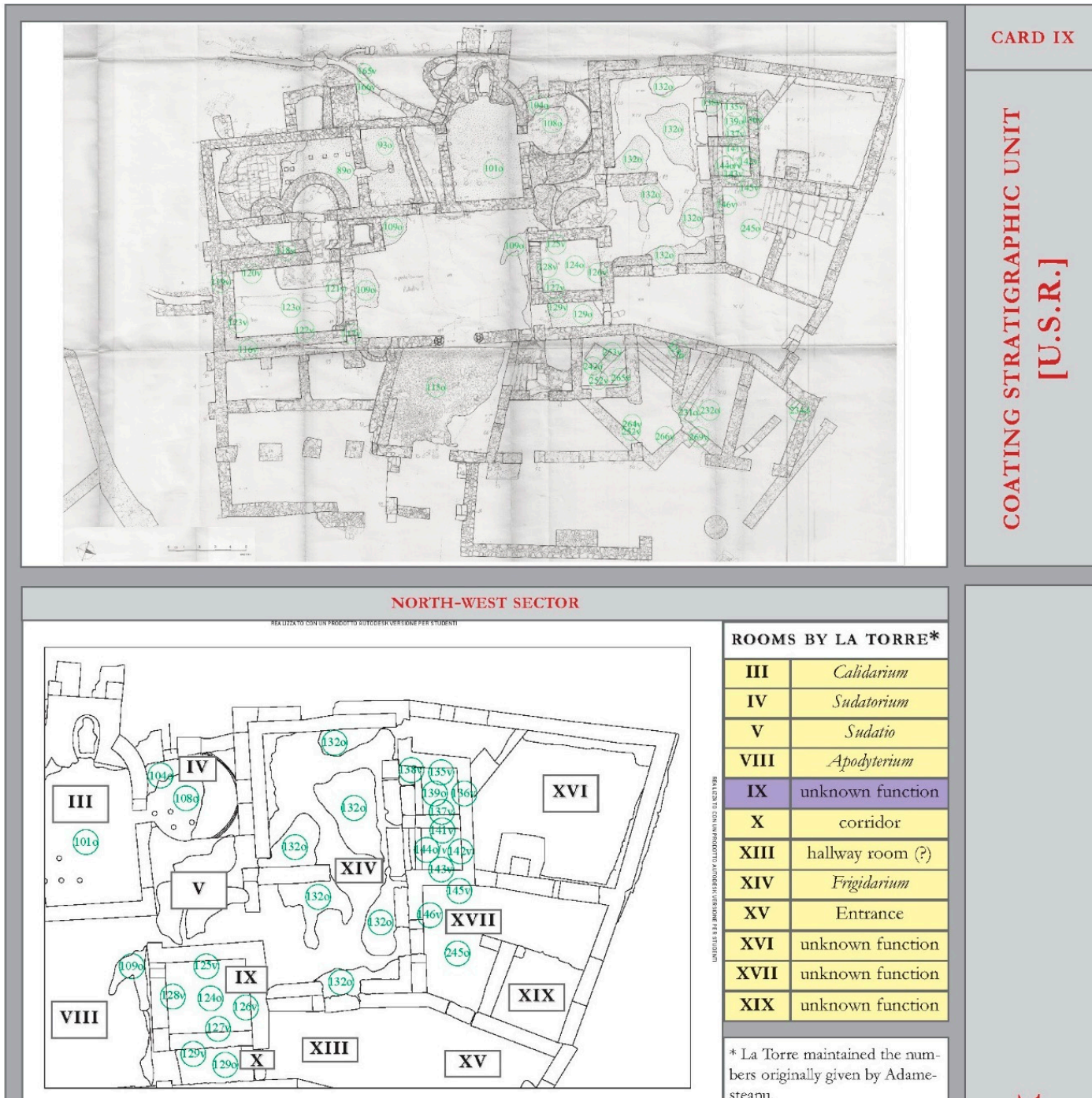

\begin{tabular}{|c|c|}
\hline \multicolumn{2}{|c|}{ ROOMS BY LA TORRE* } \\
\hline III & Calidarium \\
\hline IV & Sudatorium \\
\hline V & Sudatio \\
\hline VIII & Apodyterium \\
\hline IX & unknown function \\
\hline X & corridor \\
\hline XIII & hallway room (?) \\
\hline XIV & Frigidarium \\
\hline XV & Entrance \\
\hline XVI & unknown function \\
\hline XVII & unknown function \\
\hline XIX & unknown function \\
\hline
\end{tabular}

* L a Torre maintained the numbers originally given by Adamesteanu.

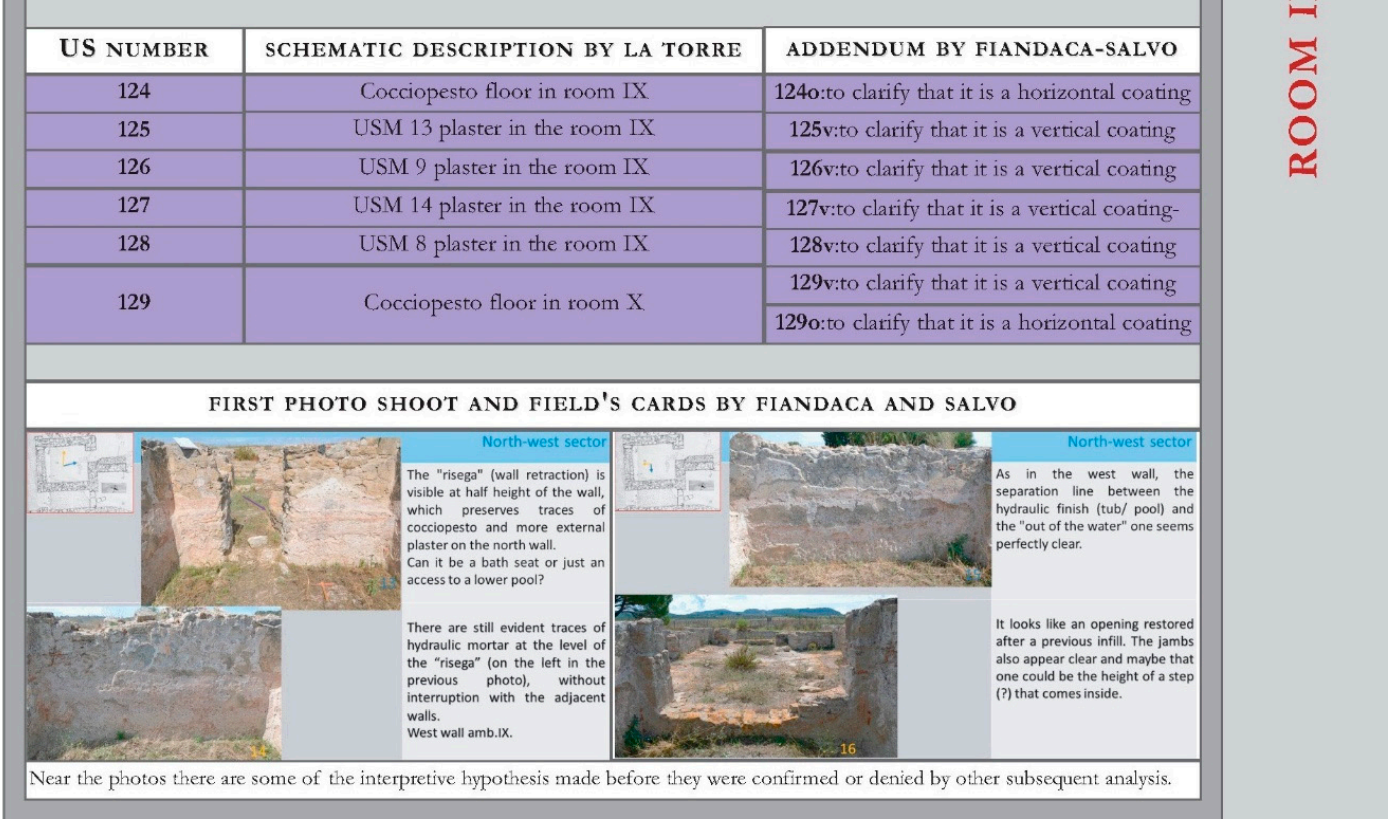

(e)

Figure 12. Cont. 

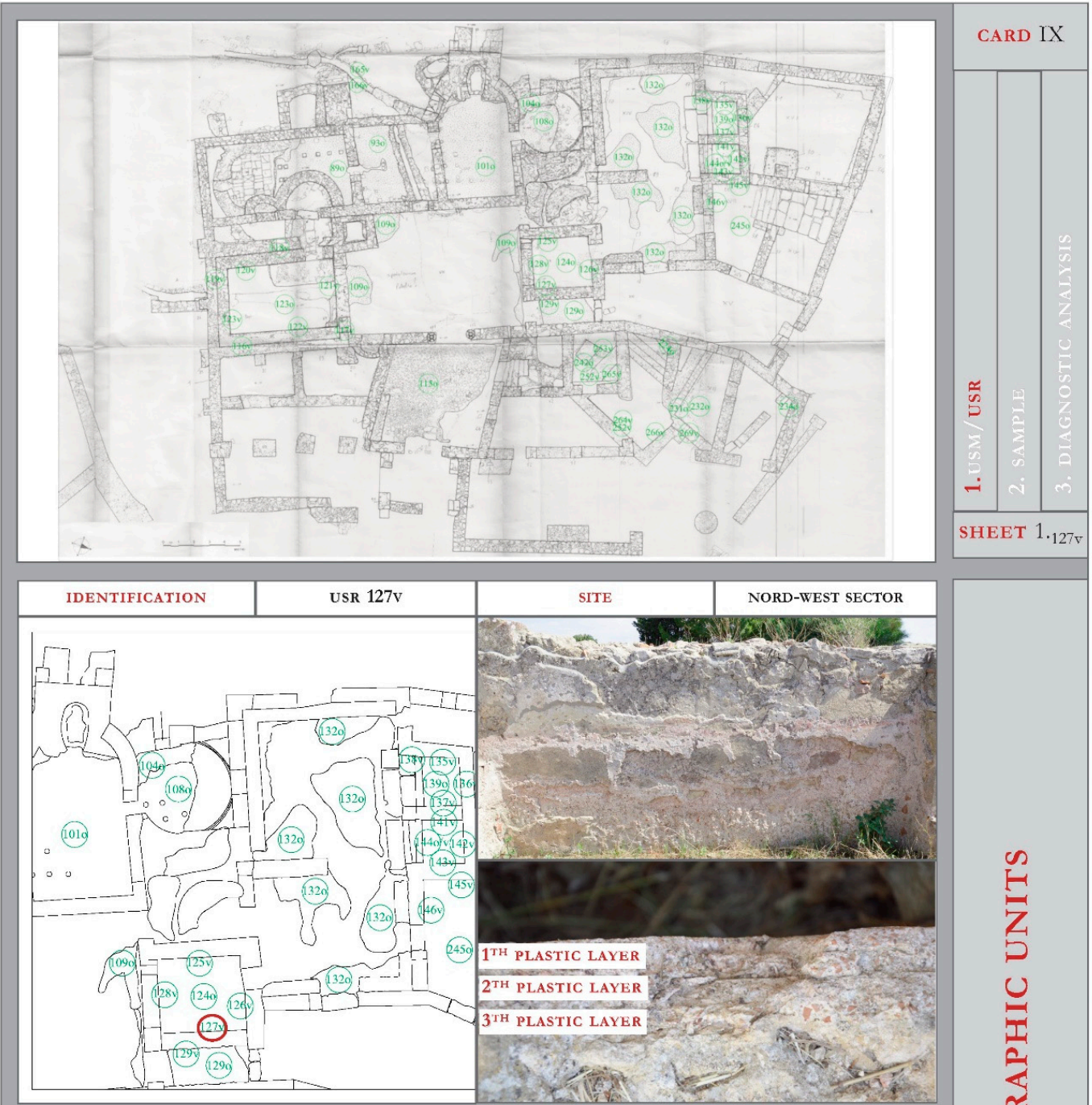

\begin{tabular}{|c|c|}
\hline \multicolumn{2}{|r|}{ BUILDING MATERIALS AND CONSTRUCTION TECNIQUE } \\
\hline COATING TYPE & E2 \\
\hline TYPOLOGICAL DEFINITION & Cocciopesto plaster in three layers \\
\hline DESCRIPTION & $\begin{array}{l}\text { Three layers of plaster: } \\
\text { the first formed by mortar with stone flakes; } \\
\text { the second consisting of a "cement" of mortar and crushed bricks (or pozzolana); } \\
\text { the third, finally, consists of a very thin layer of lime mortar with a very fine powder } \\
\text { selection or minimal fragments of cocciopesto }\end{array}$ \\
\hline
\end{tabular}

FIRST PHOTO SHOOT AND FIELD'S CARDS BY FIANDACA AND SALVO

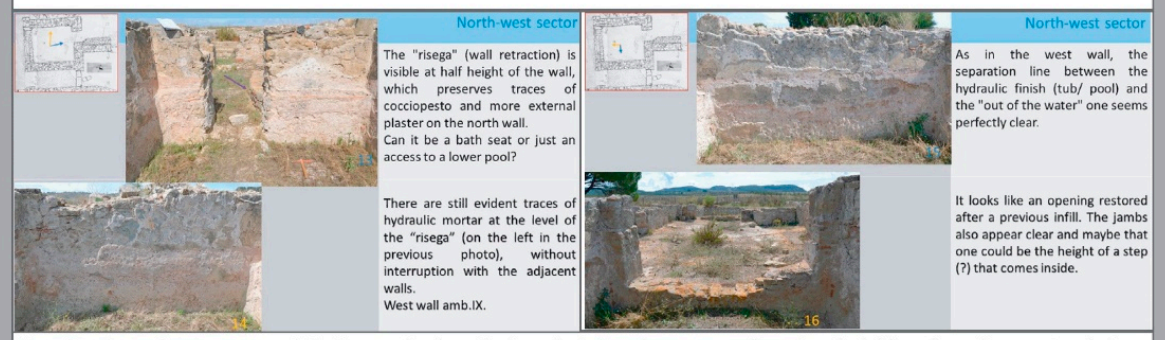

Near the photos there are some of the interpretive hypothesis made before they were confirmed or denied by other subsequent analysis.

告

(f)

Figure 12. Cont. 

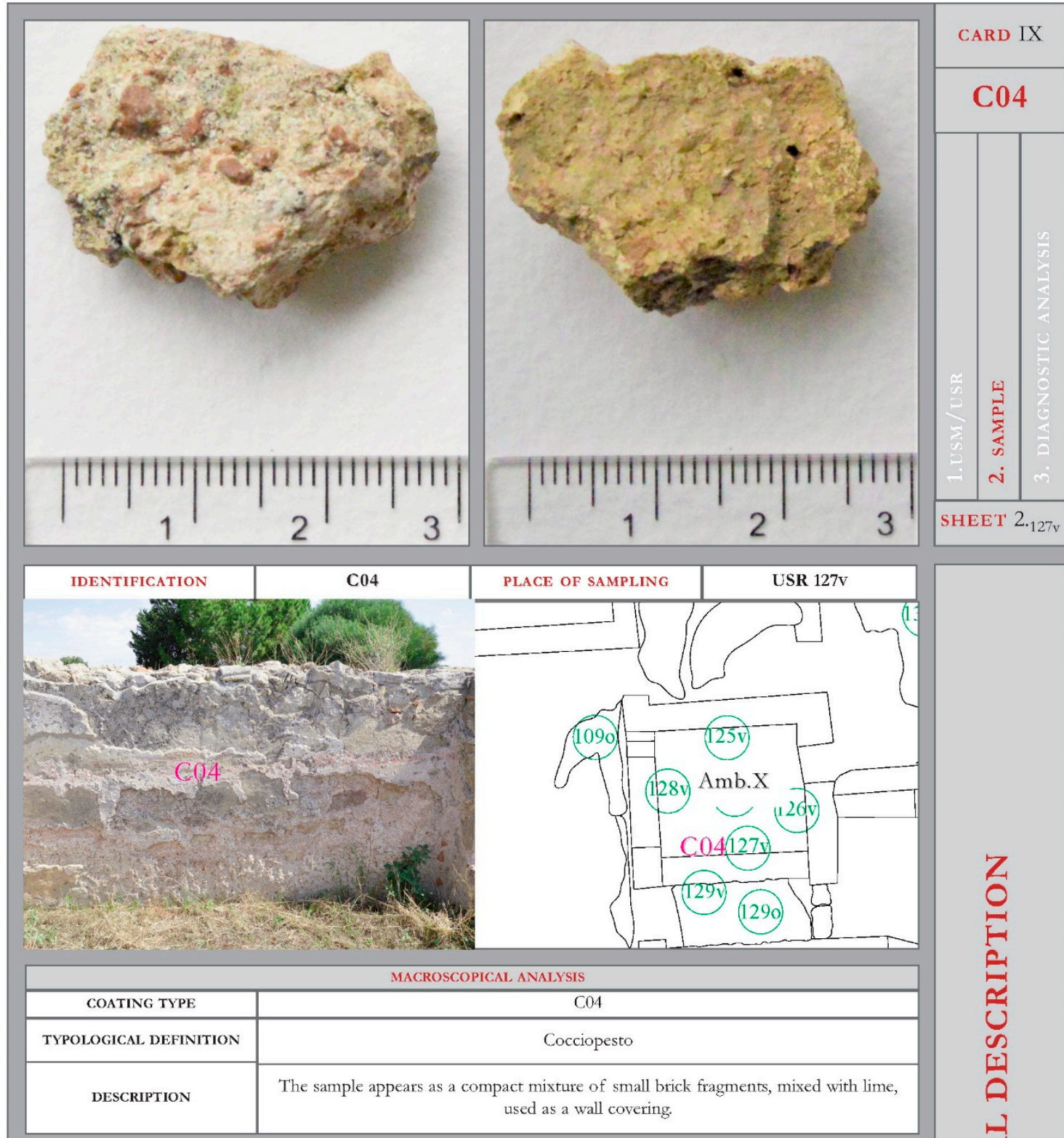

INTERPRETATION

In our case the uniform covering of the whole room (even on the floor) could suggest the purpose of waterproofing and therefore that the room was a tub or a tank for the water supply of the thermal pools.

The dimensions of the bricks "fragments", the different nature of the clay elements even if not of the agglomeration mortars, emerged from the comparison of the diagnostic investigations for the sample C04 (red part), with the analogous ones for $\mathrm{C} 05, \mathrm{CO} 61$ and $\mathrm{CO} 6$ 2, as well as the different techniques of found installation, allow to advance the hypothesis of different construction phases attributable to the Constantinian (C04, C05 and C06_2) and imperial (Tiberian age, according to La Torre) epochs. This is confirmed by the location of the USRs, and the attributions previously made by La Torre Vaccato et alii are confirmed with objective data.

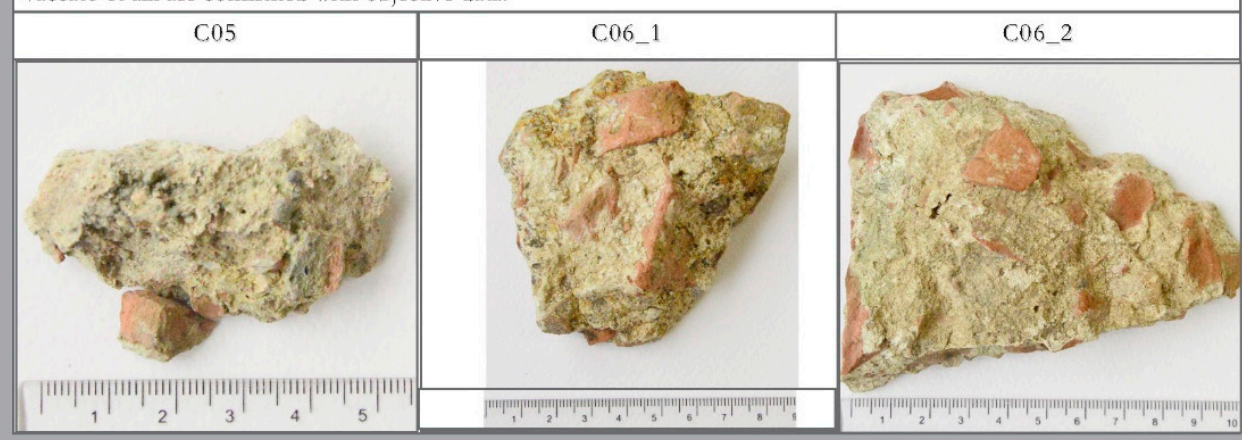




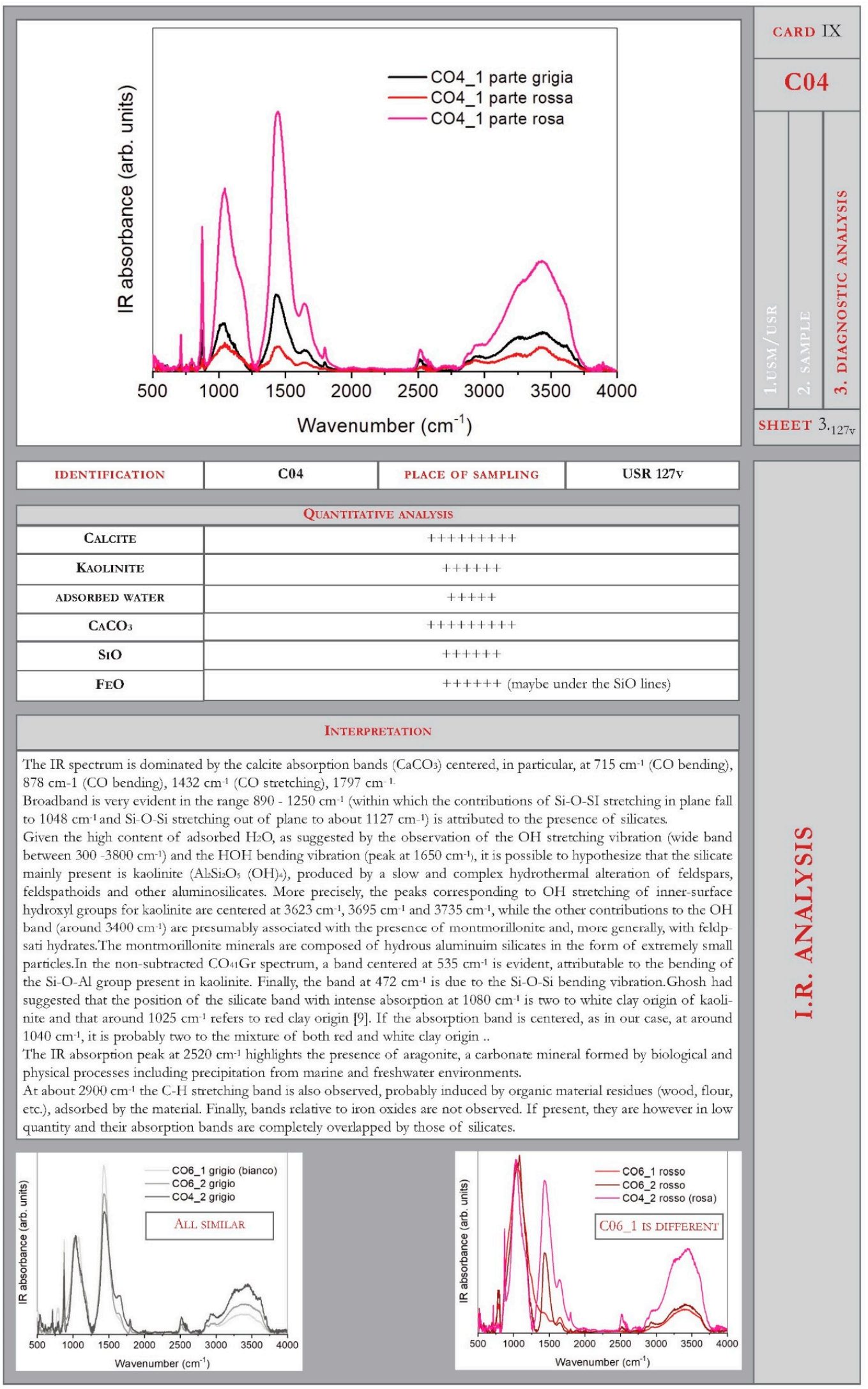

(h)

Figure 12. (a). Masonry Stratigraphic Units—the USM general card; (b). USM 14 sheet 1; (c). USM 14 sheet 2; (d). USM 14 sheet 3; (e). Cladding Stratigraphic Units-the USR general card; (f). USR 127v sheet 1 ; (g). USR $127 \mathrm{v}$ sheet 2 ; (h) USR $127 \mathrm{v}$ sheet 3. 


\section{Results: The Potential of the ArcheoGis Project}

At the end of filing of the USM and USR, all material produced was conveyed and included in the ArcheoGIS project in terms of contextual deepening that can be consulted through interactive external links (Figure 13). Each masonry, cladding or constructive element identified as a separate stratigraphic unit thus becomes a queryable and "navigable" object which allows any operator, public or private, who is responsible for the safeguard and promotion of this archaeological heritage, access to the results [12-14].

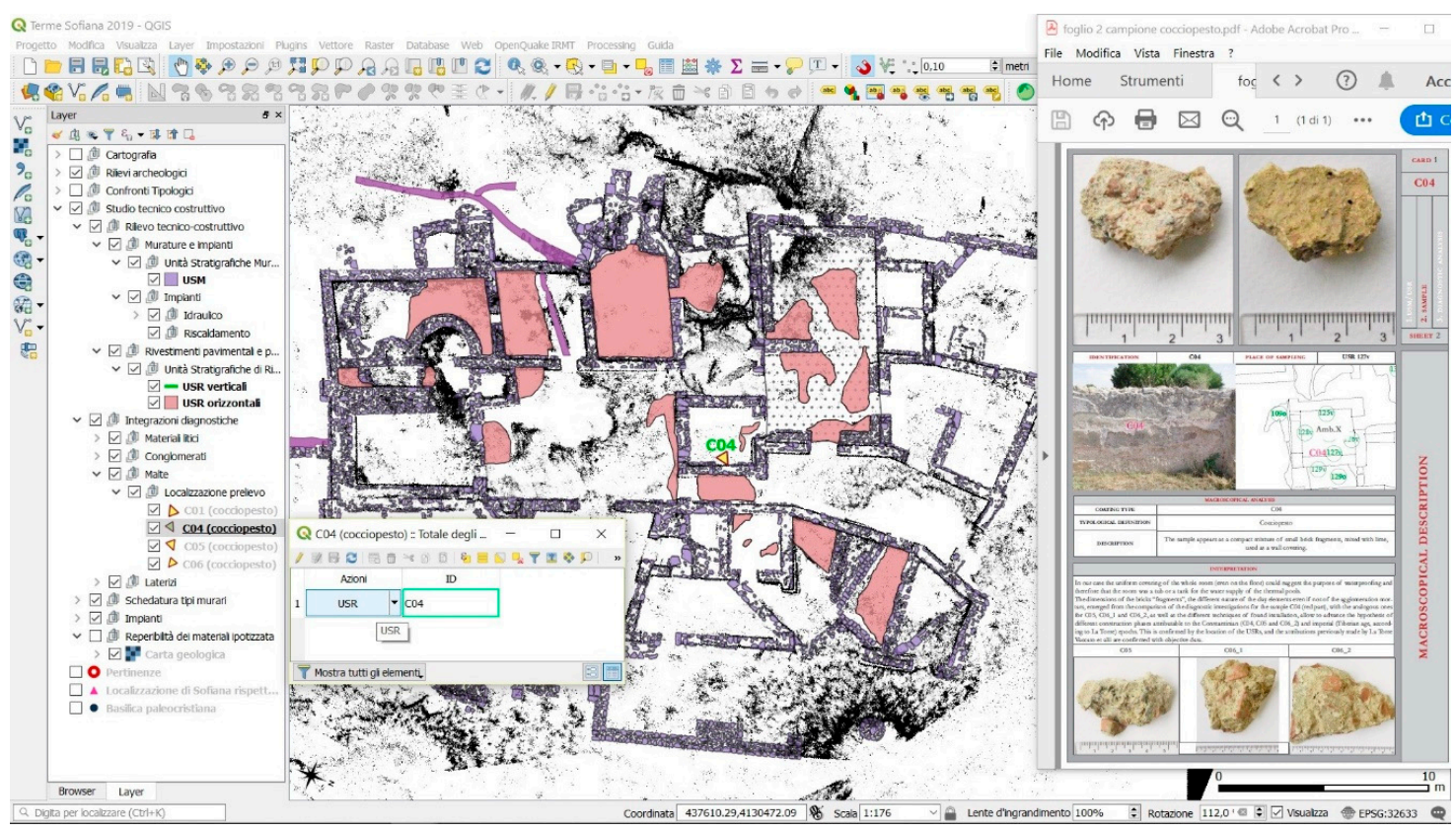

Figure 13. Example of an external connection to the USR card.

The present study, of which any results are only preliminary, generally conjugated means, tools and multidisciplinary knowledge to systematically coordinate all of the data conceived in the "digital container". It is a variegated tool and is always open to new contributions from research and different kinds of addendum (graphic, photographic, textual, visual, historical or modern) produced. This makes the preliminary knowledge from elaborations and interpolations of surveys, comparisons, and analyses available for any "real" restoration intervention, but will also allow the objective proposed-the creation of an archaeological model with H-BIM tools that is able to perform virtual restorations.

\section{Discussion: The Meaning and Future of the Work in Progress}

In this phase of the ArcheoGis project, tested on the Sofiana thermal complex, it is opportune to clarify that we have entered into the promising panorama of correlations built between the traditional operating methods of archaeological investigations and the computerised management of data. These were obtained by applying information platforms that are already active or as outcomes of specifically developed protocols.

However, we want to clarify the context for which this application was conceived; on completion, it will be named ArcheoGis-Terme di Sofiana to highlight both its method and its "originality".

It was not a question of combining digital technologies such as drones, photo reconstructions, or digital recordings of excavation campaigns in progress, but rather, of resuming a site-by this time on the confines of adjacent digs for new finds- "solved" by archaeological expertise in the 1950s to the 1990s. The site was also subjected to a "disabling" restoration of knowledge, having suffered an incompleteness or absence of several documentary supports (excavation registers, surveys, 
photographic documentation, restoration descriptions) which were perhaps lost during the formation and reconstitution of the Sicilian Superintendencies.

Therefore, as this archaeological complex faced different and multidisciplinary optics (geometric-dimensional, material-constructive, typological-distributive), it is important to go back to the "essence" and retrace the excavation campaigns to try to fill the gaps "left on the field" with technological means and tools (laser scanner, diagnostic analysis, typological overlapping) and with the help of GIS methodology to localize, integrate, and contain all the acquired data, and to test the same with an H-BIM methodology for an archaeological modelling.

Starting from the point cloud created by the laser scanner and the construction of parametric information objects for data families-rooms and intended uses, walling systems (USM), wall and floor coverings (USR), thermal and hydraulic systems-we tried to introduce the time element of the historical phases to which they have been related to the reliefs, to the investigations, and to the comparisons.

The unveiling of the history experienced by this monumental archaeological find that we have had the opportunity to investigate closely will constitute a method for other forgotten or abandoned sites of which we all want to know the past events.

We believe this methodology, however, can also support further excavations in progress since the engineering optics can provide important analytical data for the archaeological panorama.

Author Contributions: This work, conceived according to a unitary design has seen the following specification of individual contributions: conceptualization, O.F.; methodology, O.F.; software, G.S.; investigation, Diagnostic Laboratories (cfr Acknowledgments); data curation, O.F.; writing—review and editing, O.F., G.S.; supervision, O.F.

Funding: This research received no external funding.

Acknowledgments: We thank Alessio Altadonna and Giuseppe Martello, technicians of the Laboratory of Representation of the Engineering Department of the University of Messina, for the survey carried out with the 3D Laser Scanner Multistation-Leica Nova MS50 R2000. It is divided into two stadiums: The first, in site, involved the identification of five stations located in such a way as to cover the area under study, the positioning of the targets for the creation of a specific topographic network, the setting of the instrument with the typing of points, and finally, the scanning for the creation of the point cloud; in addition, the instrument made an extensive photographic investigation, correlated with the portions found. The second method of data post-processing carried out in the laboratory using Leica Cyclone 9 software was necessary to correct the margin of error inherent in the survey to generate the point cloud and to produce the 2D and 3D models; therefore, this made the geo-referencing of the digital survey possible as well as its association with elaborate metadata. The mineralogical-petrographic study of the stone materials was carried out by microscopy on a glossy section (NORMAL 10/82-14/83) through the identification of the mineralogical phases of mortars and concretes by X-ray diffractometry (NORMAL 27/88). We thank Letterio Mavilia for having conducted this process at the Laboratory of Materials for Restoration (MA.RE.) of the Department of Heritage, Architecture and Urban Planning, "Mediterranea" University of Reggio Calabria. The observations and photographic documentation of the glossy sections was performed with a EUROMEX Model S stereo-microscope equipped with a KAMPRO digital camera (model KC-25-H "PG), MicroMax shooting software, and Primo image storage. For the X-ray analysis on powders, a BRUKER Model D8 Advance diffractometer equipped with DIFFRACplus EVA Software was used for the identification of the crystalline phases. Fourier transform infrared spectroscopy (FTIR) measurements were carried out by the FTIR Bomem DA8 Spectrometer on brick and cocciopesto samples at the laboratory of Raman Spectroscopy and IR by the research group coordinated by Domenico Majolino from the Department of Mathematics and Computer Science, Physical Sciences and Earth Sciences, University of Messina. We would like to thank Valentina Venuti from the Department of Mathematics and Computer Science, Physical Sciences and Earth Sciences and Vincenza Crupi of the Department of Chemical, Biological, Pharmaceutical and Environmental Sciences.

Conflicts of Interest: The authors declare no conflict of interest.

\section{References}

1. Amico, V.A. Dizionario Topografico Della Sicilia (1756), Tradotto dal Latino e Annotato da G. Di Marzo; Tipografia di Pietro Morvillo: Palermo, Italy, 1858; Volume 1, pp. 236, 307, 459, 494.

2. La Torre, F.G. Gela sive Philosophianis (It. Antonini 88,2): Contributo per la storia di un centro interno della Sicilia Romana. Quaderni dell'istituto di archeologia della facoltà di Lettere e Filosofi dell'Università di Messina 1994, 9,99-139. 
3. Adamesteanu, D. Sofiana. Scavi 1954 e 1961. In Atti della IV riunione scientifia: La villa del Casale di Piazza Armerina; Scuola di Perfezionamento in Archeologia Classica dell'Università di Catania: Catania, Italy, 1984; pp. 74-83.

4. Wilson, R.J.A. Sicily under the Roman Empire. The Archeology of a Roman Province, 36 b.C.a.D. 535; Aris \& Phillip: Warminster, UK, 1990.

5. Angelini, A.; Gabrielli, R. Laser scanning e photo scanning. Tecniche di rilevamento per la documentazione 3D di beni architettonici ed archeologici. Archeologia e calcolatori 2013, 24, 379-394.

6. Progetto Campus Pompei. Rilievo Digitale Integrato dell'anfiteatro nel sito Archeologico di Pompei. Available online: www.Campuspompei.it/2015/02/25/larea-archeologica-di-pompei-sistemi-di-fruizione/ (accessed on 15 November 2018).

7. Fiandaca, O.; Salvo, G. La restituzione virtuale di un sito archeologico. Il complesso termale di Sophiana. In Atti del Convegno Internazionale REUSO, Sobre una Arquitectura Hecha de Tiempo; EUG_Editorial Universidad Granada: Granada, Spain, 2017; pp. 159-166.

8. Rizza, S. Nuovi rilievi degli ambienti termali di Santa Venera al Pozzo. In L'area archeologica di Santa Venera al Pozzo-ACIUM: Antiquarium; Branciforti, M.G., Ed.; Regione Siciliana, Assessorato Regionale dei beni culturali: Palermo, Italy, 2006; pp. 47-58.

9. Iannicelli, S.; Ippolito, G.; Frumento, F.; Milazzo, S. Vito Soldano tra continuità e trasformazioni. In Paesaggi urbani tardoantichi. Casi a confront; Parello, M.C., Rizzo, M.S., Eds.; Atti delle Giornate Gregoriane, VIII edizione (29-30 Novembre 2014); Edipuglia: Bari, Italy, 2016.

10. Campisi, T. Terme e Bagni di Sicilia. Caratteri di Un'architettura Specialistica; 40due edizioni: Palermo, Italy, 2015.

11. Fiandaca, O.; Salvo, G. L'area archeologica di Sophiana. Rilettura critica degli interventi eseguiti per ristabilire i capisaldi di un progetto di fruizione. In Atti del convegno internazionale di Bressanone: Eresia e ortodossia del restauro; Driussi, G., Biscontin, G., Eds.; Arcadia Ricerche Edizioni: Venezia, Italy, 2016; pp. 617-628.

12. Gaiani, M.; Bonfigli, M.E.; Calori, L.; Brunelli, D.; Farella, E.; Benini, L.; Riccò, B. Realtà virtuale come strumento di lavoro per il restauro architettonico e archeologico: Il 3D Virtual GIS "La via Appia antica". In Atti della giornata di studi: UT NATURA ARS, Virtual Reality e archeologia; Coralini, A., Scagliarini, D., Eds.; University Press: Bologna, Italy, 2007; pp. 107-113.

13. Von Schwerin, J.; Richards-Rissetto, H.; Remondino, F.; Agugiaro, G.; Girardi, G. The MayaArch3D project: A 3D WebGIS for Analyzing Ancient Architecture and Landscapes. Lit. Ling. Comput. 2013, 28, 736-753. [CrossRef]

14. Sfacteria, M. Fotomodellazione 3D e rilievo speditivo di scavo: L'esperienza del Philosophiana Project. Archeologia e calcolatori 2016, 27, 199-217.

15. Sfacteria, M. Un Approccio Integrato al Problema della Ricostruzione della Viabilità Rimana in Sicilia. La via Catania Agrigento; BAR: Oxford, UK, 2018; pp. 31-33. 